doi: $10.14664 / \mathrm{rcvs} / 257$

\title{
Early prevention of the antisocial behaviour of youth: situation in Latvia
}

\author{
Ilona Kronberga
}

\begin{abstract}
Riassunto
L'opinione comune sulla prevenzione è spesso molto limitata e stigmatizzata: il concetto di prevenzione è più frequentemente collegato al crimine piuttosto che al comportamento antisociale. Di frequente tale approccio limita non soltanto l'ambito dell'utilizzabilità e del contenuto dei metodi di prevenzione, ma anche l'età dei bambini per i quali si possono utilizzare in maniera appropriata questi metodi. In tal senso, è quindi possibile avanzare un'ipotesi: un intervento riuscito di prevenzione di un comportamento antisociale nell'ambito del lavoro effettuato con bambini piccoli riduce la necessità di agire con interventi di prevenzione della delinquenza negli anni successivi del loro sviluppo. Di conseguenza, questo articolo si focalizzerà sull'utilizzo e sulla pratica dei metodi di prevenzione nei primi anni di sviluppo di un bambino - scuola dellinfanzia e scuola primaria.
\end{abstract}

\section{Résumé}

L'opinion publique sur la prevention est souvent perçue à travers des termes trops restrictifs et stigmatizés: le concept de prévention est le plus souvent lié à la criminalité qu'au comportement antisocial. Bien souvent, de tels propos limitent non seulement la compréhension de la possibilité d'utilisation des méthodes de prévention, mais aussi l'âge auquel ces méthodes peuvent être utilisées avec succès. C'est dans ce sens qu'il est possible d'avancer une hypothèse : la prévention réussie du comportement antisocial dans le cadre de l'intervention pour les enfants en bas âge réduit la nécéssité de son maintien après. Par conséquent, cet article va examiner l'utilisation et la pratique des méthodes de prévention précoce dès l'école maternelle et primaire.

\section{Abstract}

Public opinion on prevention is often very narrow and stigmatised: the concept of prevention is more often related to a crime than to antisocial behaviour. Often such approach limits not only the understanding of the usability and content of prevention methods but also the age of children at which a successful use of these methods is acceptable. Due to the aforementioned, it is possible to put forward a hypothesis: successful prevention of antisocial behaviour in the work with children at a young age decreases the necessity of crime prevention in later years of children and youth development. Therefore, this publication will focus on the use and practice of prevention methods in the early period of child development - pre-school and primary school.

Key words: antisocial behavior; children, Latvia, early prevention; restorative justice.

\footnotetext{
- Senior Policy Analyst, Centre for Public Policy PROVIDUS, Latvia.
} 


\section{Why early prevention?}

The results of our recent studies ${ }^{1}$ show that the reasons for juvenile delinquency appear much earlier than their obvious consequences which are already the subject for the intervention of law enforcement agencies. If we assume that adults have to take care of the child's development starting from his/her birth and ensure the environment that would be appropriate for such development, we have to admit that deformed or antisocial behaviour is the consequence of the lack of such care.

Adults in particular are responsible for the fulfilment of the youngster's special development needs ${ }^{2}$. It is significant to recognise that the juvenile delinquency as an act of socially deformed behaviour shows that the rights of the particular child have been previously violated and his/her interests have been disregarded or neglected. The lack of care and treatment, indifference, parent and other adults' unwillingness to understand and fulfil the child's needs lead to the commitment of a criminal act ${ }^{3}$. Therefore it is important to develop such systems of prevention and justice within which it is possible already in the early years of the child's development to discover, recognise and prevent future situations where the child becomes an offender or a victim or even only starts behaving

1 Child-friendly Justice in Latvia: Focusing on Crime Prevention, 2012, http://www.providus.lv/public/27732.html In English: http://www.providus.lv/public/27745.html (last visited on 15.05.2015).

2 Ibidem.

${ }^{3}$ Restorative Justice in the Aspect of Juvenile Delinquency: The Baltic States in European Dimension, 2010, http://politika.lv/article files/1899/original/bez sak umlapas lv.pdf?1339440221 In English: http://politika.lv/article files/1900/original/bez sak umlapas en.pdf?1339440243 (last visited on 25.05.2015). in a way that could be called antisocial opposite to the ethical and normative requirements of the social life in the community. Child-friendly justice system has a big role in preventing the child from the consequences of illegal behaviour, performed by the child himself/herself or other persons. Though, it has to be taken into consideration that a childfriendly justice system is not only the one that is easily understandable both for the children and their parents and the specialists who work with and for children and serve their best interests, but also the one that consists of effective preventive components for all the age groups of children. It has to be considered that in case when the crime is committed by a minor the offender is also a victim at the same time: "A minor or a juvenile whose life has been influenced by the commitment of a crime and the punishment is still in need of support and will be able to contribute to the society much later while many of them will not be willing or able to do that ever. Due to those reasons it is exactly the development and implementation of various preventive measures that have to be given the main role in the juvenile justice in order to prevent crimes before they are committed"4.

Public opinion on prevention ${ }^{5}$ is often very narrow and stigmatised: the concept of prevention is more often related to a crime than to antisocial behaviour. Very often such approach limits not only the understanding of the usability and content of

\footnotetext{
4 Child-friendly Justice in Latvia: Focusing on Crime Prevention, 2012, op. cit.

5 Prevention: a system of methods that is created from such mutually related tools that provide a possibility to avert a criminal act or intervene before the commitment of such act.
} 
prevention methods but also the age of children at which a successful use of these methods is acceptable. Due to the aforementioned, it is possible to put forward a bypothesis: successful prevention of antisocial behaviour in the work with children at a young age decreases the necessity of crime prevention in later years of children and youth development. Therefore, this publication focuses on the use and practice of prevention methods in the early period of child development - preschool and primary school (year 1 - 4) age when, from the point of view of our legislation ${ }^{6}$, it is not possible to speak about particular offences and prevention as the tool for reducing such offences, but rather as the method of early intervention.

\section{Early prevention of antisocial behaviour?: why it is so important?}

The majority of the most recent studies ${ }^{8}$ suggest that the prevention measures of antisocial behaviour should begin in the womb and continue all through the first years of a baby's life. Antisocial behaviour is harmful not only to

${ }^{6}$ Author's note: children who are not subjects of administrative violations or criminal legal relations (a); children who have not reached the age which is related to prevention by the major part of the society, i.e. - long before adolescence (b).

7 Author's note: here, antisocial behaviour is understood both as deviance (antisocial behaviour in its wider meaning), and delinquency (antisocial behaviour that manifests itself in the form of punishable illegal activities). See also: deviance: A diversion of acts from legal or moral norms, standards accepted by the society, http://www.tezaurs.lv/sv/?w=deviance; delinquency: $1^{\text {st }}$ meaning (in medicine) $=$ An offence or a minor crime, such as lying, theft, sexual perversity, $2^{\text {nd }}$ meaning (in psychology) $=$ Punishable act http://www.tezaurs.lv/sv/?w=delinkvence (last visited on 20.05.2015).

8 Delinquency Prevention \& Intervention: Juvenile Justice Guide Book for Legislators, the child or adolescent himself/herself as it may lead to drug dependency, offending, dropping out of school, incarceration and ruin the future but it also causes harm to the community, first of all, to the family. In order to have a maximum effect of eliminating the progress of the child's antisocial behaviour two activities have to be performed: risks to the child's development have to be identified and averted as soon as possible (a) and protective factors have to be developed (b).

In this case, the following factors are identified as risk factors:

a) individual risks (early antisocial behaviour, poor cognitive development, hyperactivity and other emotional stability factors);

b) family risk factors (poor relations between the parents and children, poverty, maltreatment, violence, divorce, parental psychopathology, familial antisocial behaviours, teenage parenthood, single parent family and large family size);

c) friends from risk groups (friends with antisocial behaviour; peer rejection);

d) school and community risk factors (failure to bond to school, poor academic performance, neighbourhood disadvantage, disorganized neighbourhoods, easy access to drugs and toxic substances).

The following protective factors are opposed with the above mentioned risk factors:

a) regular school (pre-school) attendance;

http://www.ncsl.org/documents/cj/jiguidebookdelinquency.pdf (last visited on 20.05.2015). 
b) motivation to learn, acquire new skills, participation in extra-curriculum activities;

c) positive attitude about the world in general;

d) ability to discuss problems with parents and family;

e) positive adult example.

It is considered that by activating protective factors it is possible to minimise also the already existing antisocial behaviour risks; both risk and protective factors are integral part of antisocial behaviour prevention and intervention planning. Antisocial behaviour prevention and interventions are applied to reduce risk factors and activate protective factors. Nowadays, antisocial behaviour prevention measures have usually been aimed at school-age children, more often at adolescents. In recent years, early prevention methods have been used more often containing planned interventions at an earlier period - starting from the pregnancy, over preschool age and up to the moment of adolescence. In order to plan and apply prevention programmes for children with developmental disorders and antisocial behaviour a very close inter-institutional cooperation is needed. To adopt the framework of such cooperation it is necessary to be able to resign the traditional concept of prevention from the point of view of law enforcement system only. Early prevention of antisocial behaviour is a set of inter-institutionally and purposefully planned activities on condition that its application is based on a close and coordinated cooperation among various institutions, such as health protection system, social services, organizations for the protection of the rights and interests of the child, local municipalities, all level education institutions and law enforcement agencies. It has to be taken into consideration that in early prevention system law enforcement agencies have a) a protective not punitive role, b) the role to be applied the last and only in case of failure of all the previously mentioned protective factors.

According to the concept of early prevention ${ }^{10}$, antisocial behaviour prevention and intervention measures have to be planned in accordance with the stages of the child's development:

a) pre-natal stage. It is considered that the first 33 weeks in utero are the most important in the child's psycho-emotional development. If the mother-to-be spends this time in a destructive or harmful environment the child develops instinctive protective mechanisms that may manifest as hyperactivity, lack of self-control after the birth of the child and in his/her further stages of development, besides, such children have a bigger inclination to stress and violence;

b) early childhood, pre-school stage. One of the main tasks in this age is to protect the child from the exposure to violence. Studies conducted in the USA ${ }^{11}$ state that there is a clear correlation between the children's violence, lack of care and attention during the childhood and antisocial behaviour over the life of the person. It has been recognised that $59 \%$ of the children to whom their freedom was limited by law enforcement

\footnotetext{
${ }^{9}$ Ibidem.

${ }^{10}$ Ibidem.

11 Berson S. B., Hernon J, Pearsall B., Preventing Children's Exposure to Violence: The Defending Childhood Initiativeby,
} 
agencies in the form of detention, imprisonment or deprivation of liberty as a punishment had been exposed to various forms of violence, whereas $27 \%$ of adults had such experience. Among children who were victims of violence $24 \%$ were children suffering from repeated violence. One-third of the people detained for violent child abuse had suffered from various forms of violence in their childhood. In this case, not only physical violence should be taken into account. Also in cases when the violence is of psycho-emotional nature or if the child has witnessed violence it definitely has influence on the child's development and mental health which may later develop in post-traumatic stress syndrome, inability to form positive relations with other people, cause an increased tolerance for violence, difficulties to learn and acquire new information. However, these are not the only considerations for ensuring successful children's development at an early age and successful prevention of antisocial behaviour.

There are a lot of studies ${ }^{12}$ showing that at the early stages of the child's development the physical - emotional link between the baby and the person who is together with the child in his/her first years of life plays an important role. So called "attachment theory" has been analysed in a row of publications ${ }^{13}$ which conclude that there is a correlation between a successful development of the child at infancy and early childhood stage and the necessity to build safe relations with parents or the person who cares

http://www.nij.gov/journals/270/pages/defendingchildhood.aspx (last visited on 20.04.2014).

12 Attachment theory, http://www.childencyclopedia.com/en-ca/parents-childattachment/according-to-experts.html (last visited on 20.05.2015). for the child. It is stated that the existence of safe relations at an early age of the child's development creates protection not only against external stress situations in the further life of the child but also enhances the child's mental health and prevents antisocial behaviour risks. Byron Egeland writes ${ }^{14}$ that the attachment arises from two significant segments: psychopathology and normal socio-emotional development. The theory is based on the idea that the early relationship that develops between the infant and his/her caregiver provides the foundation for later development of the child. B. Egeland emphasises that it is rather a pattern of emotional and behavioural interaction that develops over time between the child and his/her caregiver in the context of the infant's needs and bids for comfort and care ${ }^{15}$. Successful development of such care forms the first relations in the child's life with another person, based on confidence and trust and as the result mutual understanding appear. In a natural process, this person, indisputably, is the mother. In such interaction, the first social reflexes of the child develop: if the child's mother (primary caregiver) is calm and in a comforting and safe contact with the child thus answering his/her needs, the child seeks the contact with his/her mother to find a solution to his needs and gets calmed finding it. This pattern has been labelled

\footnotetext{
13 Ibidem.

14 Egeland B., "Attachment-based intervention and prevention programs for young children", in Tremblay R.E., Boivin M., Peters R.D.(eds.), Encyclopedia on Early Childhood Development, Centre of Excellence for Early Childhood Development and Strategic Knowledge Cluster on Early Child Development; Montreal, Quebec, 2009, pp. 1-8. Available at: $\quad$ http://www.childencyclopedia.com/pages/PDF/EgelandANGxp rev. pdf (last visited on 28.05.2015).
} 
secure. If there is no such contact or if the child's needs are not comforted the trust does not develop and the child will not accept other people as safe and trustworthy partners. Over time, the child will stop seeking contact in fear of rejection. This pattern has been labelled insecure. The existence (or lack) of safe attachment at early childhood denotes further social development of the child during the childhood and adolescence. This is the exact period when the acquired instinctive experience develops the abilities of social interaction, empathy for others, behaviour. If the child has experienced negative attachment there is a bigger risk of problematic relation formation and behaviour. Positive attachment experience works as a protective factor in further stages of the child's development and it has a long-term impact on the developmental process of the child's personality. B. Egeland indicates ${ }^{16}$ that positive attachment experience, as children grow up, creates similar relationship models with their own children: young parents who have had secure relations with their parents form secure and trustful relations also with their children. Due to that there is a ground to consider that the formation of secure relationships in early childhood has a serious impact on the child's future life therefore it is worth providing support to parents (families) with young children

\footnotetext{
15 Ibidem.

16 Egeland B., "Attachment-based intervention and prevention programs for young children", in Tremblay R.E., Boivin M., Peters R.D.(eds.), Encyclopedia on Early Childhood Development, Centre of Excellence for Early Childhood Development and Strategic Knowledge Cluster on Early Child Development; Montreal, Quebec, 2009, pp. 1-8. Available at: $\quad$ http://www.childencyclopedia.com/pages/PDF/EgelandANGxp rev. pdf (last visited on 28.05.2015).
}

at risk. This support should contain early prevention methods that are suitable for parents and children's needs and appropriately organised. It is stated that the closer are the relations of the child with his/her mother, the less likely the child is to be at risk for antisocial influence in his/her later development ${ }^{17}$;

c) school age. A row of studies emphasise that preventive measures before reaching adolescence have a particularly important role in the child's development. They prepare the child for the changes appearing during adolescence. During this time one of the strongest negative traits is influence from delinquent peer groups. Other prominent risk factors for children at this age are related to the inability to follow the process of education, academic failure, and decreased connection with school environment. School and events related to the process of education in general play an important role in the child's life. School is particularly the environment where the early prevention programmes are to be implemented. These programmes can address almost all negative risk groups in the school environment: drug and alcohol abuse, bullying and humiliation. In fact, education institutions as places where children spend most of their time have all the opportunities to plan and apply the necessary preventive programmes: disciplining children, creating and analysing various behavioural models together with children and their parents, strengthening the relations among the school, parents (families) and children.

\footnotetext{
17 Loeber R., Farrington D.P., Petechuk D., Child Delinquency: Early Intervention and Prevention, https://www.ncjrs.gov/pdffiles1/ojjdp/186162.pdf (last visited on 22.05.2015).
} 
Studies ${ }^{18}$ show that all the early prevention interventions have to be focused on particular children's risk groups. An instrument for risk and needs assessment is necessary to identify these risks. Nevertheless, it has to be taken into consideration that early prevention target groups fundamentally differ from those with which law enforcement agencies work. If the needs of the clients of law enforcement agencies are usually based on prevention (from particular actions) or various methods of disciplining, early prevention programmes, in their turn, are based on an inclusive process - restoration of justice, skills development, relationship building, development of emotional skills. Due to that, early intervention planning process should not involve such complicated risk and needs assessment tools which are used for high or relatively high risk offenders' needs and risk assessment, for instance, when planning particular sentence execution 0or probation processes. It is important to note that the programmes that are applied as early prevention tools have to be proved and evidence-based. One of the most widespread groups of programmes in the USA is multi-systemic $^{19}$ therapy programmes that include a purposefully oriented set of activities to help parents of children with behavioural problems. The programme develops parental

\footnotetext{
${ }^{18}$ See, for instance: Lipsey M. W., Tanner-Smith E.E., Wilson S.J., Treatment for Adolescent Substance Use Disorders: What Works?, Peabody Research Institute, Vanderbilt University, JMATE, December 2010, http://peabody.vanderbilt.edu/docs/pdf/pri/JMAT E\%20plenary Lipsey.pdf, links to other external sources from PRI: http://peabody.vanderbilt.edu/research/pri/publicat ions.php\#crime (last visited on 22.05.2015).

19 Multisystemic Therapy for Juvenile Offenders, http:/ / evidencebasedprograms.org/1366-

2/multisystemic-therapy-for-juvenile-offenders (last visited on 20.04.2014).
}

skills and communication quality between the child and the parents, as well as among the child's family members. Another programme is functional family therapy ${ }^{20}$ which is aimed at children with antisocial behaviour, inclination for drug and alcohol abuse, as well as at the children who have been exposed to domestic violence. It has to be noted that these programmes are flexible to apply: one programme may have various results and multidisciplinary benefits.

\section{Approaches for the prevention of} children's antisocial and problematic behaviour in Latvia: practice and legal framework.

Problematic and antisocial behaviour in children and crime prevention of children and youth (juveniles) in Latvia is understood in a narrower sense than in the publications and studies analysed in the previous chapters. The concepts of early prevention and intervention are not defined as well as they are not included in legislative instruments. Despite the fact that prevention is a set of purposefully developed activities, formally it is split with a high level of institutionalization for some parts of it. Therefore, inter-institutional cooperation framework fails to form in practice, although it is the main pre-condition for the implementation of prevention. As the result, there is a situation that prevention measures related to a range of specific risks of children's age groups does not

\footnotetext{
20 Functional Family Therapy (FFT), http://www.blueprintsprograms.com/factSheet.php? pid $=0 a 57$ cb53ba59c46fc4b692527a38a87c78d84028 and also: https://www.crimesolutions.gov/ProgramDetails.asp $\mathrm{x}$ ?ID=122 (last visited on 20.05.2015).
} 
work or work insufficiently. Traditionally, prevention in Latvia is related to children and youth who already show serious behavioural risks or are in serious risk situations, or have already committed crimes. Activities that are aimed at children until one year of age or at early childhood stage are not classified as prevention. As the result, children of that age are not included in the comprehensive net of prevention or safety; instead, such services are ensured which are considered the most necessary for the particular age group by the respective responsible institutions within the framework of their competence and thus correspond to this competence.

In fact, prevention does not include also children in cases of early problematic behaviour. It is formed to react only when any consequences appear that can be formally registered. It has to be evaluated positively that recently, when prevention measures slowly play more and more important role in the community, several publications have been made with the research scope on juvenile delinquents or the implementation of social assistance and social behavioural correction programmes. The multidisciplinary nature of the practical implementation of all type prevention measures has also been analysed and found its place both in the studies, and the methodology materials, thus stimulating the development of interinstitutional cooperation and the formation of inter-institutional workgroups in regions.

However, looking from the aspects of prevention theory, including that of early prevention, which has been analysed in the previous chapters, it is obvious that prevention, in fact, includes purposeful measures that are oriented to the child's successful development and last from the pregnancy till maturity (a), and envisages early interventions (b), which do not need any formal consequences as the ground for the initiation of their implementation. Based on the nature of early prevention, it is enough with considered worries about the risks against the child's development or the existence of such risk situation to start the implementation of prevention measures. Besides, it has to be taken into account that the group of preventive activities that is oriented at a wider society (for instance, children's parents in general) or at a particular group of society, has to be performed also without the recognition of risks for particular individuals or groups but it has to be based on facts and practices proved in research. Only in cases when the child already shows antisocial behaviour or is in the situation that is in any way risky for his/her further development individual prevention programmes should be implemented in the form of interventions.

The guidelines for the prevention of juvenile delinquency and protection of children against crime 2013 - 2019 clearly show that the lack of early prevention system as well as the systemic deficiencies of prevention measures lead towards a constant fight of law enforcement and education institutions with the consequences that appear as the result of a late reaction to the problems of the child and the family at an early stage. Although the number of crimes committed by children in Latvia is decreasing, it has to be related with a significant decrease in the number of children in Latvia in general. Child crime rate in Latvia is still high: "...the overall statistics on the registered crimes and persons who have committed them show the 
tendency of decrease in juvenile delinquency both in short term and medium term. Analysing the statistical data, it has to be taken into consideration that the overall number of children in the country is decreasing. According to the data from the OCMA Population Register, from 1 January 2009 till 1 January 2012 the number of children registered in the country has decreased by 21330 children $(-5,8 \%)$, but the number of registered juveniles has decreased even by 23804 (-23,95\%). In 2011, 907 crimes committed by juveniles were disclosed and taken to court. Comparing the data from 2011 with the data from 2008, the number of crimes committed by juveniles has decreased by 490 criminal acts $(-35,07 \%)$. In the first 9 months of 2012, the accusation was initiated for 668 crimes committed by juveniles. In 2011, juveniles committed 420 serious crimes. In three years, the number of serious crimes committed by juveniles has decreased by 180 crimes (- 30\%), nevertheless, it has to be admitted that the rate of serious crimes has remained at a high level (in $2008-42,94 \%$, in $2011-46,3 \%$, in 9 months of 2012 - 40,26\%). The most popular types of crimes committed by juveniles are: theft, hooliganism and robbery".

Also the number of victimised children decreases. At the same time it has to be noted that the tendency of children suffering from violence particularly in their families increases. The guidelines for the prevention of juvenile delinquency and protection of children against crimes 2013 - 1019 state that most frequently juveniles suffer from burglary and hooliganism against them, forcible sexual assault, rape, leading to depravity, cruelty and violence, including domestic violence. The authors of the guidelines base their conclusions on studies which state that children in Latvia suffer from being beaten by parents, sexual abuse in family, emotional violence, being left without care. It is emphasised that the numerous cases of termination of parental and custody rights prove that very often parents do not change their behaviour against children and fail or cannot do parenting in an adequate manner.

The study shows that young children in Latvia are particularly unprotected against violence; the lack of parental care is often connected with high level of children traumatism already at early age, including the cases when young children become victims of violence resulting in injuries or even death. Moreover, young children are exposed to the risks of emotional and physical violence also at educational institutions, including exclusion, name-calling, taking away belongings, slander. The guidelines for the prevention of juvenile delinquency and protection of children against crimes 2013 2019 indicate that education institutions do not have access to efficient mechanisms how to avert such violence. The studies show that education institutions would be glad to develop a violence prevention plan but they lack knowledge in this field or common basic principles. Frequently, teachers feel helpless to change things for better because parental participation and work of other responsible institutions is passive therefore each school solves conflicts among students within their possibilities.

Taking into consideration the problems in creating safe environment for children's development, as referred to in the Guidelines for the prevention of juvenile delinquency and 
protection of children against crimes 2013 2019, attention has to be turned towards the Guidelines on the National family policy for 2011 - 2017. These guidelines mention a list of problems that still have not awaited their solution during several years:

a) A large number of children suffer from various traumas the reason of which is very often unsafe environment and the lack of parental responsibility and attention;

b) service providers' offers are hardly appropriate or inappropriate for families, especially for families with young children, as well as for children with special needs, for instance, child care services, baby nursing rooms, safe trading, recreation and entertainment places; c) pedagogues lack knowledge and comprehension about the most appropriate action how to avert complicated situations when a social or critical problem has to be solved;

d) there is no inter-institutional cooperation among agencies and institutions that should be involved in the provision of the necessary support to families;

e) children lack understanding about the issues related to the family: planning, values, distribution of responsibilities, child upbringing and care - the lack of these skills have a negative impact on their future lives and results in repeating their parents' negative experience;

f) the acquisition of social skills in family and school is related to various stereotypes on the person's role in the community and family. It often creates low self-confidence, fear of mocking and a desire to humiliate others thus compensating the lack of the person's inner confidence; g) reaching the age of majority young people have not acquired the necessary skills and abilities to find occupation to make a living. Adolescents have limited accessibility to professional skills acquisition possibilities within the system of education and in practical work.

In order to solve the identified problems, the programme has key directions for activities and results but the activities are fragmented and do not give a unified, purposeful and systemic set of solutions that would aim at the identification and effective elimination of the mentioned problem causes before unwanted consequences for children's development and safety appear.

The general liability of a child for violations of law and prevention thereof is provided for in Chapter 9 of the Protection of the Rights of the Child Law. However, the attention has to be turned towards the fact that this legal framework is applied only for children with already existing behavioural risks as well as for the children who have already committed criminal acts. Article 58 of the Protection of the Rights of the Child Law defines the procedure for the organisation of work for the prevention of violations of law committed by children. Although Part 1 of Article 58 determines that the work with children for the prevention of violations of law shall be carried out by local governments in collaboration with the parents of children, educational institutions, the State police, State Probation Service, public organisations and other institutions, it does not stipulate directly the inter-institutional nature of preventive work. Due to that, this legal enactment gets interpreted very widely or ignored by its applicants. Besides, Part 1 of Article 58 of the Protection of the 
Rights of the Child Law does not get related to Part 4 of Article 210 of the Latvian Administrative Violations Code that stipulates that local governments may establish a subcommission for child matters of the administrative commission in order to examine at least those administrative violations that are committed by children who have reached 14 years of age. Practice analysis shows that the advantages of inter-institutional cooperation are important, therefore several municipalities of Latvia, on the basis of Part 4 of Article 210 of the Latvian Administrative Violations Code establish inter-institutional cooperation groups aimed at the cases of juvenile administrative violations and discussions on urgent issues related to the prevention of children's antisocial behaviour. Nevertheless, this is not at all the best version for the implementation of prevention measures in an inter-institutional level because of the lack of proper legal framework for the practical work.

Part 2 of Article 58 of the Protection of the Rights of the Child Law narrows the possibilities to apply this legal provision for prevention as its terms and provisions in practice are applied only for the groups of children referred to in this legal enactment. Namely, children who: have committed criminal offences and are not in detention during the pre-trial investigation period (a); are found guilty of the commission of the criminal offence but the sentence is not connected with deprivation of liberty (b); are released from criminal liability (c); are released from imprisonment or from the place where they are serving sentence (d); have committed illegal acts set out in the Criminal Law prior to attaining 14 years of age (e); have committed illegal acts as set out in the Administrative Violations Code more than two times ( $\mathrm{f}$; begs, is vagrant or performs other acts which may lead to illegal actions (g).

From the point of view of early prevention of children antisocial behaviour it is worth paying attention to the Prevention of the Rights of the Child Law, Article 58, part 2, point (g) that stipulates that local governments establish a prevention file and formulate a social behaviour correction programme for each child who not only begs, is vagrant but also performs other acts which may lead to illegal actions. It has to be mentioned that this provision is applied in practice in the context of the provisions set out in Part 2 of Article 59 of this law. They stipulate that in cases provided for in this particular article, the conveyance of a child to the police is permissible if it is not possible to provide assistance to the child in another way. At the same time, it has to be admitted that the evaluation on whether particular acts of the child may lead to illegal activities has to be done by a person who is able to identify such activities. Thus, it can be concluded that any adult whom the child meets on daily basis - parents, teachers, social workers, pedagogues of extra curriculum activities, sport trainers, police officers and others - may be classified as such persons. In fact, it means that in order to have Article 58, part 2, point (g) of the Protection of the Rights of the Child Law work properly these adults should be able to identify children behavioural risks - it means, actions as the result of which the child may become an offender and/or cause damage to other persons, as well as be able to deliberately intervene in this situation with such methods that would stop the acts which may 
lead to illegal activities and prevent the identified risks.

It is clear that the identification, recognition and elimination of the child's antisocial behaviour risks at early stage of their development are possible only by deliberate planning and performance of preventive work. However, early prevention of antisocial behaviour is possible also without the implementation of the complicated mechanism regarding the risks, namely - by involving young children and their parents in particular activities of individual prevention. The Protection of the Rights of the Child Law does not stipulate the age of the child to whom a prevention file should be established and the social behaviour programme should be developed. There is no doubt that in this way the legal framework includes all persons who have not attained 18 years of age. Even interpreting Article 58 and 59 of the Protection of the Rights of the Child Law in a very narrow sense, prevention activities for children at early childhood are possible.

In order to clarify how the prevention measures provided for in the Protection of the Rights of the Child Law are applied in practice, at the end of 2013 the Ombudsman's office of Latvia conducted a research which stated that in 18 local municipalities in Latvia the age border for the application of social behaviour programmes is not set; 2 municipalities start them at preschool age (3 years of age); 2 municipalities start the programme when the child is 5-6 years old; 21 municipality - at school age (7 years), other much later. It cannot be stated from the above mentioned information that those 18 municipalities that do not have age borders for the initiation of preventive work certainly perform early prevention. It is possible to conclude that in 43 municipalities, possibly, particular prevention activities are carried out for young children aged 3 to 10 . In 48 municipalities, however, early prevention with young children most probably is not performed at all as they apply prevention measures only for children starting from 11 years of age. Quantitative results of the study show that the majority of local municipalities have very poor or hardly any preventive work with children from all age groups.

\section{New approach to an early prevention.}

In order to motivate specialists to develop new, not only external resource-dependant, approaches for prevention, including early prevention of children's antisocial behaviour and developmental disorders, at the end of 2013 the Centre for Public Policy PROVIDUS started the implementation of the project "Reducing youth at risk numbers: modelling early childhood intervention approaches".

The project is based on the bypothesis that a child's antisocial behaviour is a consequence of ignoring the child's needs in his/her early childhood. Therefore, the objective of the project is to develop innovative methods for social work in regions of Latvia to reduce risks that cause antisocial behaviour in children. The target group includes 48 children that are exposed to risks of social exclusion and their families. The project has been initiated in Kuldīga ${ }^{21}$, Saldus ${ }^{22}$

\footnotetext{
${ }^{21}$ More about Kuldīga at: http://kuldiga.lv/en/ (last visited on 29.05.2015).

22 More about Saldus at: http://www.saldus.lv/en (last visited on 29.05.2015).
} 
and $\mathrm{Ce}^{-} \mathrm{sis}^{23}$, whereas the international experience is obtained from Bulgaria and other countries in the European Union.

Project activities include:

a) work with parents and children in regions of Latvia;

b) establishment of inter-institutional cooperation groups with an objective to ensure intensive exchange of information among the responsible institutions and organisations while ensuring also a regular review of on-going problems, finding solutions and setting up an inter-institutional coordination;

c) increasing the professionalism of specialists, including through consultations with colleagues from other regions;

d) identification and implementation of the best practices.

The project is planned to finish on 31 October 2015 and result in the promotion of change in philosophy when working with children and families, including the application of various early prevention methods, and the formation of children-friendly and inclusive society both in particular regions of the country and in Latvia in general. The specialists involved in the project are working on the models of inter-institutional cooperation which would be efficient particularly in their municipalities. The elaboration of methodology plays a significant role in order to identify and prevent behavioural risks in children in due time, as well as to implement early prevention measures in preschools and primary schools. At the final stage of the project PROVIDUS researchers will introduce the wider

${ }^{23}$ More about Cēsis at: http://www.cesis.lv/en (last visited on 29.05.2015).
EU society with the results and findings of the study.

\section{Bibliography.}

- Berson S. B., Hernon J, Pearsall B., Preventing Children's Exposure to Violence: The Defending Childhood Initiativeby, http://www.nij.gov/journals/270/pages/de fending-childhood.aspx (last visited on 20.04.2014).

- Egeland B., "Attachment-based intervention and prevention programs for young children", in Tremblay R.E., Boivin M., Peters R.D.(eds.), Encyclopedia on Early Childhood Development, Centre of Excellence for Early Childhood Development and Strategic Knowledge Cluster on Early Child Development; Montreal, Quebec, 2009, pp. 1-8. Available at: http://www.childencyclopedia.com/pages/PDF/EgelandAN Gxp_rev.pdf (last visited on 28.05.2015).

- Judins A., Pelikan C., Ūsele L., Tamma K., Restorative Justice in the Aspect of Juvenile Delinquency: The Baltic States in European Dimension, 2010, http://politika.lv/article files/1899/original Lbez sakumlapas lv.pdf?1339440221 In English:

http://politika.lv/article files/1900/original /bez_sakumlapas en.pdf?1339440243 (last visited on 25.05.2015).

- Kronberga I., Zermatten J., Child-friendly Justice in Latvia: Focusing on Crime Prevention, 2012,

http://www.providus.lv/public/27732.html In English: http://www.providus.lv/public/27745.html (last visited on 15.05.2015).

- Lipsey M. W., Tanner-Smith E.E., Wilson S.J., Treatment for Adolescent Substance Use Disorders: What Works?, Peabody Research Institute, Vanderbilt University, JMATE, December 2010, http://peabody.vanderbilt.edu/docs/pdf/pr i/JMATE \%20plenary Lipsey.pdf, links to other external sources from PRI: http://peabody.vanderbilt.edu/research/pri Lpublications.php\#crime (last visited on 22.05.2015).

- Loeber R., Farrington D.P., Petechuk D., Child Delinquency: Early Intervention and Prevention, 
https://www.ncjrs.gov/pdffiles1/ojidp/186 162.pdf (last visited on 22.05.2015).

Internet sources on the topic of publication.

- Attachment theory, http://www.childencyclopedia.com/en-ca/parents-child-

attachment/according-to-experts.html (last visited on 20.05.2015).

- Functional Family Therapy (FFT), http://www.blueprintsprograms.com/factS heet.php?pid $=0 \mathrm{a} 57 \mathrm{cb} 53 \mathrm{ba5} 9 \mathrm{c} 46 \mathrm{fc} 4 \mathrm{~b} 692527$ a38a87c78d84028 and also: https://www.crimesolutions.gov/ProgramD etails.aspx?ID=122 (last visited on 20.05.2015).

- Multisystemic Therapy for Juvenile Offenders, http://evidencebasedprograms.org/13662/multisystemic-therapy-for-juvenileoffenders (last visited on 20.04.2014).

- Delinquency Prevention \& Intervention: Juvenile Justice Guide Book for Legislators, http://www.ncsl.org/documents/cj/ijguide book-delinquency.pdf (last visited on 20.05.2015).

\section{Other internet sources.}

- About Cēsis: http://www.cesis.lv/en (last visited on 29.05.2015).

- About Kuldīga: http://kuldiga.lv/en/ (last visited on 29.05.2015).

- About PROVIDUS: http://providus.lv/en (last visited on 30.05.2015).

- About Saldus: http://www.saldus.lv/en (last visited on 29.05.2015). 